\title{
A survey of silage management practices on California dairies
}

\author{
J. M. Heguy, ${ }^{*}$ D. Meyer, $†$ and N. Silva-del-Río $\S^{1}$ \\ *University of California Cooperative Extension, 3800 Cornucopia Way, Suite A, Modesto 95358 \\ †Department of Animal Science, University of California, Davis, One Shields Avenue, Davis 95616 \\ ¥Veterinary Medicine Teaching and Research Center, 18830 Road 112, Tulare, CA 93274 \\ §Department of Population Health and Reproduction, School of Veterinary Medicine, University of California, Davis, One Shields Avenue, \\ Davis 95616
}

\section{ABSTRACT}

The aim of the present study was to gather baseline information on corn silage-management practices to develop an outreach curriculum for dairy producers and growers. In spring 2013, dairy producers in the San Joaquin Valley (California) were surveyed on their silage-management practices. Response rate was $14.5 \%(\mathrm{n}=160)$ and herd size averaged 1,512 milking cows. Harvest date was set solely by the dairy producer $(53.4 \%)$ or with the assistance of the crop manager, custom chopper, or nutritionist (23.3\%). On some dairies $(23.3 \%)$, the dairy producer delegated the harvest date decision. Most dairies (75.0\%) estimated crop dry matter before harvest, and the preferred method was milk line evaluation. Dairy producers were mostly unfamiliar with harvest rate but the number $[1$ (35.9\%), $2(50.3 \%)$, or 3 to $5(13.8 \%)]$ and size [6-row $(17.7 \%)$, 8-row (67.3\%), or 10-row (15.0\%)] of choppers working simultaneously was reported. Most dairies used a single packing tractor $(68.8 \%)$ and weighed every load of fresh chopped corn delivered to the silage pit $(62 \%)$. During harvest, dry matter (66.9\%), particle length (80.4\%), and kernel processing (92.5\%) were monitored. Most dairies completed filling their largest silage structure in less than $3 \mathrm{~d}(48.5 \%)$ or in 4 to $7 \mathrm{~d}(30.9 \%)$. Silage covering was completed no later than $72 \mathrm{~h}$ after structure completion in all dairies, and was often completed within $24 \mathrm{~h}$ (68.8\%). Packed forage was covered as filled in $19.6 \%$ of dairies. Temporary covers were used on some dairies (51.0\%), with filling durations of 1 to 60 d. When temporary covers were not used, structures were filled in no more than $15 \mathrm{~d}$. After structure closure, silage feedout started in 1 to $3 \mathrm{wk}(44.4 \%)$, 4 to 5 wk $(31.4 \%)$, or 8 or more wk $(24.2 \%)$. Future considerations included increasing the silage storage area $(55.9 \%)$, increasing the number of packing tractors $(37.0 \%)$, planting brown mid-rib varieties $(34.4 \%)$,

Received July 3, 2015

Accepted October 2, 2015.

${ }^{1}$ Corresponding author: nsilvadelrio@ucdavis.edu buying a defacer to remove silage (33.1\%), and creating drive-over piles (32.6\%). Survey results will serve to develop and disseminate targeted information on silage management practices at harvest, packing, covering, and feedout on California's San Joaquin Valley dairies. Key words: corn silage, California, dairy, survey

\section{INTRODUCTION}

Forage production and preservation is key to profitable dairying in many regions. Selection of forage type and preservation method is driven by dietary needs (i.e., energy and protein), climate, soil conditions, available equipment, and so on. Ensiling allows for rapid removal of plant matter, quick turnover from one crop to the next, and accomplishes forage preservation. Increased herd size, volatility in feed price and availability, and increased regulatory scrutiny over the last few decades have resulted in greater need to understand and improve silage preservation and feedout management to increase profitability, reduce losses, and maintain quality feed during feedout. In recent years, emphasis has been placed on homegrown, high-quality silage and reducing silage losses to offset increasing feed prices (alfalfa, commodities, and imported grains). This is particularly important for California dairy production systems, where feed is the major operating cost. In 2012 , feed accounted for $65 \%$ of the total cost to produce milk in California (CDFA, 2012). Until recently, regulatory considerations were not a factor in the way dairy producers grew, harvested, stored, and fed silage. Today, California dairy producers in the San Joaquin Valley comply with strict air- and water-quality regulations. These regulations affect decisions made on the dairy, including quantity of manure applied to silage crops, the formation of silage piles, and the management of feed, especially silage to animals.

Eight of the top 10 dairy-producing counties in California comprise the San Joaquin Valley, accounting for $88 \%$ of California's milk production (CDFA, 2012). Corn silage was identified as the most commonly fed ensiled forage to dairy cows (Silva-del-Rio et al., 2010). 
In $2012,172,000$ ha of silage corn were planted in California, yielding 11,263,000 tons of corn silage (USDA, 2014). The objectives of our study were to understand current silage management practices on California's San Joaquin Valley dairies and identify opportunities for improved silage management practices.

\section{MATERIALS AND METHODS}

A complete list of dairy producers was obtained from the California Department of Food and Agriculture (Sacramento, CA). In April 2013, a silage-management survey was mailed to all dairy producers in California's San Joaquin Valley $(\mathrm{n}=1,100)$. Producers were mailed an invitation letter to participate in the study, a double sided 2-page survey, and a prepaid return envelope. The objective of the study, to understand current silagemanagement practices and identify opportunities for improvement, was clearly stated in the invitation letter. A $\$ 10$ value gift card was provided to the first 50 respondents to promote prompt survey return.

The survey focused on the 2012 corn harvest and addressed (1) general herd information, (2) silage structure characteristics, (3) silage harvest, (4) monitoring during silage harvest, (5) silage covering, (6) silage feeding, (7) evaluation of custom harvest services, and (8) future considerations. Questions were multiple choice or fill in the blank, with a smaller number of openended questions. Respondents were asked to rank their experience (satisfied, needs improvement, not satisfied) with using custom harvesting services in 4 areas: (1) chopping and processing, (2) harvesting at the correct DM, (3) delivery rate, and (4) packing. Future considerations were ranked as (1) I am already doing this, (2) I would like to do this in the future, or (3) I will not do this in the future.

Within each survey, responses were checked for typographical errors, logic, and completeness. Unanswered questions and questions with responses outside reasonable values were not included in the data analysis. Descriptive statistics were performed with the PROC MEANS, PROC UNIVARIATE, and PROC FREQ procedure of SAS 9.4 (SAS Institute Inc., Cary, NC). Chi-squared test was performed with the CHISQ option of PROC FREQ.

\section{RESULTS AND DISCUSSION}

At the time of survey mailing, high feed prices were driving dairy producers' interest in improving silagemanagement practices. Survey response rate was $14.5 \%$, with a total of 160 returned surveys. Five respondents had recently sold their operations and did not complete the survey, and 2 additional respondents were pasturebased operations that did not feed silage. These dairies were not included in the data summarization. Returned surveys were received 2 to $40 \mathrm{~d}$ after mailing. Overall, the error survey rate was $7.2 \%$ with a $95 \%$ confidence level (Custom Insight Inc., 2010).

\section{General Information}

Average herd size of respondents $(\mathrm{n}=153)$ was 1,512 milking cows: $13.9 \%$ had $<500,26.5 \%$ had 500 to $<1,000,30.5 \%$ had 1,000 to $<2,000$, and $29.1 \%$ had $\geq 2,000$ cows. Comparable average herd size for the survey area was 1,341 milking cows (CDFA, 2012). Hectares farmed per dairy farm ranged from 19 to 1,618 with an average of 233 farmed hectares per dairy farm.

\section{Silage Structures: Number, Type, and Surface}

Silage structures were reported as wedge piles $(33.8 \%)$, drive-over piles $(31.8 \%)$, bunkers $(7.4 \%)$, bags $(6.1 \%)$, or a combination of structures (20.9\%). Dairies reported floor base material as concrete slabs (55.4\%), earthen $(9.5 \%)$, or a combination of concrete, earthen, or gravel (35.1\%). The mean number of silage structures was 2 (range 1 to 5 ) for both corn and wheat. Excluding bags, dairies reported the maximum number of structures open at one time as $1(9.8 \%), 2(60.8 \%), 3$ (15.7\%), or more than 3 (13.7\%). Inactive silage structures (open but not used for an extended time) were reported as zero $(57.3 \%), 1(13.3 \%)$, and 2 or more $(29.4 \%)$.

\section{Silage Harvest}

On most dairies $(54.4 \%)$, the dairy producer determined corn silage harvest date. On $23.3 \%$ of dairies, silage harvest date was decided by the dairy producer and 1 or 2 members of the silage team (crop manager, custom chopper, and nutritionist). Some dairy producers delegated this decision to the custom chopper $(12.0 \%)$, crop manager $(7.3 \%)$, nutritionist $(0.7 \%)$, or combination of the custom chopper and crop manager (3.3\%). No dairies involved all members of the silage team in deciding the harvest date, and only 4 dairies involved their nutritionists. Harvest date can influence the nutritional value of the harvested forage and its potential fermentation qualities, and setting the harvest date is one of the most challenging management decisions of corn silage production. Unlike other cornproducing regions in the United States, rain forecast does not play a role in setting a harvest date in the San Joaquin Valley. Forage maturity, irrigation needs, and availability of custom choppers are variables influenc- 
ing harvest date. Survey results indicate an opportunity to increase communication among silage team members in California.

Seventy-five percent of dairies estimated crop DM before harvest and incorporated this information into harvest date selection. The preferred method of estimating crop DM was checking the milk line; only 1 dairy determined DM by shredding and drying plants before harvest. High variability between forage moisture and kernel maturity has been demonstrated (Lauer, 2006), which suggests milk line should not be used as the sole determinant of harvest moisture.

Most dairies reported 1 (35.9\%), 2 (50.3\%), or 3 (11.1\%) corn choppers operating simultaneously, with $2.7 \%(\mathrm{n}=4)$ of dairies utilizing 4 or 5 choppers. The most common chopper size was 8-row $(67.3 \%)$, followed by 6 -row $(17.7 \%)$ and 10 -row $(15.0 \%)$. When accounting for the number of choppers operating at one time and the chopper size, the number of simultaneously chopped rows ranged from 6 to 40. In most cases, a single packing tractor was used $(68.8 \%)$, with $2(29.7 \%)$ and $3(1.5 \%)$ tractors less popular options. Only 37 respondents provided delivery rate of fresh chopped material (range: 70 to 350 tons/hour). The mean delivery rate for dairies with 1,2 , or 3 packing tractors was $168.7,162.4$, and $181.4 \mathrm{t} / \mathrm{h}$, respectively. Tractor weight and time packing per ton are important factors for packing density (Muck and Holmes, 2000), suggesting that, as delivery rate of fresh chopped material to the structure increases, more packing weight is needed to reach optimal packing density. The lack of delivery rate responses indicates that this is not an area where dairy producers are involved in the ensiling process.

Sixty-two percent of dairies weighed every load of corn silage delivered to determine tonnage. When not weighing every load, dairies estimated tonnage by averaging the weights of several loads multiplied by the total number of loads delivered. Forage weights were obtained with a farm scale on $58.9 \%$ of dairies. Less frequently, forage weights were obtained with the custom harvester's mobile scale $(23.2 \%)$, other certified scale $(16.6 \%)$, or no loads of delivered forage were weighed $(1.3 \%)$. Harvested tonnage is very important for inventory purposes, but also for custom harvester payment and purchasing forage, making accurate determination of harvested tonnage desirable. Dairies not weighing every truck load of delivered forage included large herds [median (range): 750 (200-5,200) milking cows].

Most dairies filled their largest silage structure in $3 \mathrm{~d}$ or less $(48.5 \%)$ or in 4 to $7 \mathrm{~d}(30.9 \%)$. Thirty-two percent reported filling silage structures with more than 5 fields of harvested forage, composed of $1(36.8 \%)$ or 2 $(40.6 \%)$ varieties. Dairies reported as many as 5 varieties of corn silage in a single structure.
Inoculants were applied to corn silage in $55.9 \%$ of dairies. This high rate of use on corn could be linked to Rule 4570 Air Permit (SJVAPCD, 2010). Each exposed face of ensiled feed that is not in a bag needs to have to management measures employed: restrict exposed face, have smooth face, or include inoculant when material is ensiled. The most common inoculant application method was via the chopping equipment at harvest $(71.8 \%)$. Some dairies applied inoculants to the top of the truck (21.2\%), and at the silage pit during packing (7.0\%). For silage additives to work efficiently, uniform application is critical (Kung et al., 2003).

Fermentation period ranged from 1 to $300 \mathrm{~d}$ after structure closure before beginning feedout. Producers reported waiting 1 (11.1\%), 2 (13.1\%), 3 (20.2), 4 (19\%), $5(12.4 \%), 8(13.1 \%)$, or more than $8(11.1 \%)$ wk after structure closure before beginning feedout. Standard industry recommendation is to allow ensiled material to stabilize before beginning feedout. Recent studies indicated that nutrient availability might increase if feeding is postponed even longer (Hoffman et al., 2011; Der Bedrosian et al., 2012). The short waiting period from structure completion to feeding is an indication of the immediate need to incorporate the harvested forage into rations, likely because the previous year's corn silage was exhausted. Dairy producers might benefit from improving estimations of silage inventory, ensuring enough silage is available to feed until the next crop is ready.

\section{Monitoring During Harvest}

During harvest, $66.9 \%$ of the producers evaluated DM and used results to make harvesting decisions. The frequency of sampling was 1 (31.3\%), 2 (16.3\%), 3 $(11.3 \%)$, or more than $3(25.0 \%)$ times per day. A total of $16.2 \%$ of dairies based their sampling frequency on the hectares harvested. Samples were sent to a commercial laboratory $(42.7 \%)$, monitored on-farm with a koster tester $(39.6 \%)$, a microwave $(5.9 \%)$, or a combination of on-fam koster tester or microwave (11.8\%). All dairies within California's San Joaquin Valley sample plant-tissue from fields where manure is applied for regulatory compliance (California Regional Water Quality Control Board Central Valley Region, 2013) but do not necessarily use data for any other purpose. Monitoring DM during harvest is important for several reasons, including buying or selling wet forages. Taking a single sample of chopped corn to estimate DM removal of an entire field of corn silage was shown to overestimate or underestimate DM removal by as much as $20 \%$ on 3 fields of corn silage (Heguy et al., 2010).

Particle length of the fresh chopped material was monitored in $80.4 \%$ of the dairies. The majority of 
dairies evaluated chop length visually (95.7\%). Other, less popular and more precise methods of evaluating chop length included using the Penn State shaker box or a measuring tape. Likewise, most dairies (92.5\%) monitored kernel processing. Visual inspection of kernel processing was reported in $94.0 \%$ of dairies with few dairies $(6.0 \%)$ separating the fodder from the kernels using a bucket of water and evaluating the busted kernels (Shinners et al., 2006). Particle length and kernel processing scores are associated with the ability to pack forages and the starch availability respectively (Muck et al., 2003).

\section{Silage Covering}

Most dairies (68.8\%) reported covering packed forage within $24 \mathrm{~h}$ of structure completion, with all dairies covering packed forage within $72 \mathrm{~h}$. Covering packed forage as it was filled was reported in $19.6 \%$ of dairies. Fifty-one percent of dairies used a temporary cover during filling, with length of filling ranging from 1 to 60 $\mathrm{d}$ (median $=5 \mathrm{~d}$ ) on their largest corn structure. Only 9 dairies did not use a temporary cover, with filling lengths up to $15 \mathrm{~d}$ on their largest structures.

Double plastic was used to cover silage piles in $70.9 \%$ of dairies versus a single sheet of plastic. Oxygen barrier plastic was popular among dairies using double plastic, with $88.4 \%$ of those dairies using the technology, which may have resulted from Rule 4570 Air District Permit Requirement (SJVAPCD, 2010). Only one-third of the participant dairies provided information on the cumulative thickness of plastic covers. This indicates that most dairy producers are not aware of the plastic thickness used or did not have records readily available while completing their survey. Among those responding, plastic thickness was at least $5 \mathrm{~mm}$ (79.6\%), another requirement in Rule 4570.

In all dairies, plastic covers were weighted down with tires. Tire arrangement was reported as tires touching $(55.7 \%)$, some space between tires $(42.9 \%)$ or both methods (1.4\%). Dairies reported top surface spoiled forage as $<7.6 \mathrm{~cm}(51.0 \%), 7.6$ to $<15.2 \mathrm{~cm}(38.7 \%)$, and 15.2 to $<22.9 \mathrm{~cm}(10.3 \%)$; no dairy reported more than $22.9 \mathrm{~cm}$ of spoilage. A similar proportion $(P=$ 0.22 ) of dairies reported surface spoilage of at least 15.2 $\mathrm{cm}$ among those using a double $(46.2 \%)$ or a single $(33.3 \%)$ plastic sheet to cover the structure.

The plastic cover from silage structures (not including bags) was pulled back by an outside company (53.5\%), on-farm employees (41.7\%), or both (4.8\%). Plastic covers were pulled back daily to every $3 \mathrm{~d}$ in $33.1 \%$ of dairies. Plastic was removed every 4 to 7 (58.4\% of dairies) or 8 to $21 \mathrm{~d}$ ( $8.5 \%$ of dairies). Most dairies contracting with an outside company removed the plastic cover weekly (72.8\%). Dairies which relied on farm employees removed plastic daily to every $3 \mathrm{~d}$ $(63.3 \%)$. The exposed depth of pile after cover removal was 0.30 to $0.91(31.7 \%), 1.22$ to $1.83(31.7 \%), 2.1$ to $3.04(29.3 \%)$, or 3.65 to $6.10 \mathrm{~m}(7.3 \%)$. The frequency of plastic removal for dairies with at least $2.14 \mathrm{~m}$ of silage exposure depth was 1 to $7 \mathrm{~d}(88.6 \%)$. The integrity of plastic covers was evaluated at least weekly in $59.2 \%$ of dairies.

\section{Silage Feeding}

Silage was most commonly removed with a front-end loader $(85.1 \%)$, but some dairies used a rake $(10.8 \%)$ or a defacer $(4.1 \%)$. The width and depth of the face removed per day is presented in Table 1 . The entire width of the silage face was removed daily in $53.6 \%$ of dairies, and, of those, $29.3 \%$ removed less than $15.2 \mathrm{~cm}$ depth per day. Of dairies that did not remove the entire width of the silage face, $55.4 \%$ advanced less than $15.2 \mathrm{~cm}$ depth per day. Previous California work demonstrated that animal feeding units did not correlate with exposed silage surface area (Meyer et al., 2015). The current survey results also indicate that silage structures are not sized according to feedout needs in California, but are likely a function of available space and forage quantity. The feedout rate of silage has important implications on the quality and quantity of the ensiled crop. In well-compacted silage structures, oxygen has been detected $(>10 \mathrm{~mL} / \mathrm{L})$ at $1 \mathrm{~m}$ of depth from a face that was not undergoing heating (Muck and Huhnke, 1995). Thus, 10 to $15 \mathrm{~cm}$ of removal rate per day might result in forage been exposed to oxygen for $7 \mathrm{~d}$. Current industry recommendations, based on field experiences in Israel, suggest that a removal rate of 20 to $30 \mathrm{~cm} / \mathrm{d}$ in warm weather is most desirable (Muck et al., 2003).

Spoiled forage was frequently discarded (50.4\%). When fed, spoiled silage was often offered to heifers or dry cows only $(33.1 \%)$, but some dairies fed it to the lactating cows $(3.0 \%)$, lactating and dry cows $(1.5 \%)$, and lactating cows, dry cows, and heifers (12.0\%). The current recommendation is to discard spoiled and moldy feed from the silage surface, as consumption of this material decreases intake and digestibility and destroys the rumen forage mat (Whitlock et al., 2000).

Determination of silage DM for feeding purposes was conducted 1 to 3 times per week (27.9\%), ' to 3 times per month (57.8\%), and 1 to 6 times per year (14.3\%). A total of $49.3 \%$ of the dairies reported checking DM on farm. On-farm DM evaluations were done using a koster tester (76.4\%), a microwave $(20.6 \%)$, or a food dehydrator (3.0\%).

Silage sample collection for DM determination was done by an outside nutrition consultant (51.4\%), the 
Table 1. Corn silage removal rates (face width and depth) in the San Joaquin Valley

\begin{tabular}{lccccc}
\hline & \multicolumn{4}{c}{ Depth of face removed $(\mathrm{cm})$} & \\
\cline { 2 - 5 } Width of face & $<15.2$ & 15.2 to $<30.5$ & 30.5 to $<45.7$ & $\geq 45.7$ & Total $^{1}(\%)$ \\
\hline removed & 22 & 15 & 20 & 19 & 53.9 \\
Whole & 6 & 6 & 6 & 3 & 14.9 \\
Half & 8 & 7 & 14 & 10 & 27.7 \\
Third & 0 & 2 & 1 & 2 & 3.5 \\
Fourth & 25.5 & 21.3 & 29.1 & 24.1 & \\
Total $(\%)$ & & & & \\
${ }^{1} \mathrm{n}=141$. & & &
\end{tabular}

manager $(31.4 \%)$, an on-farm employee $(7.2 \%)$, or the task was shared across consultants, managers, and onfarm employees (10.0\%). Silage samples for nutrient analysis were collected at least every 2 wk (16.2\%), once a month $(50.0 \%), 3$ to 8 times per year (14.1\%), and 1 to 2 times per year $(19.7 \%)$. Packing density of silage structures was not evaluated $(64.8 \%)$, determined with a probe measurement $(12.0 \%)$, estimated based on volume and weight (21.8\%), or estimated with a spreadsheet calculator (1.4\%).

\section{Custom Harvesting Services}

Most dairies (89.3\%) relied on contracted custom harvesting services for crop harvest. Custom harvesting services were primarily used to harvest corn (89.3\%) and small grains $(85.2 \%)$, with a smaller percentage of dairies utilizing the services for other crops such as alfalfa and sorghum (10.1\%). Of those dairies working with custom harvesters, $9.7 \%$ considered doing their own harvesting. Custom harvester services (Table 2) were reported to be unsatisfactory or needing improvement at chopping and processing (13.0\%), at targeting the correct DM (21.0\%), at delivery rate $(24.4 \%)$, and at packing $(30.8 \%)$.

\section{Future Considerations for Silage Management}

Future considerations for silage management are summarized in Table 3. Most $(89.0 \%)$ dairies kernel processed corn silage, with only $4.4 \%$ reporting it would not be done in the future. Pouring concrete pads for silage storage $(64.7 \%)$, utilizing oxygen barrier film $(63.2 \%)$, and inoculant usage $(57.8 \%)$ were other current practices already adopted on most dairies. Increasing the silage storage area was largely reported as a practice to consider in the future $(55.9 \%)$, as well as increasing the number of packing tractors $(37 \%)$, planting brown mid-rib varieties $(34.4 \%)$, buying a defacer to remove silage $(33.1 \%)$, and creating drive-over piles $(32.6 \%)$. Harvesting corn as shredlage $(68.5 \%)$ and building bunkers $(84.3 \%)$ were practices producers would not implement in the future.

\section{CONCLUSIONS}

Corn silage is a valuable commodity. Knowing the current silage-management practices of California dairy producers helps to identify areas where improvements in forage preservation may be realized to improve silage quality. Most dairies (54.4\%) set the harvest date without consulting the crop manager, chopper, or nutritionist, an indication that communication among silage team members could be improved. The lack of responses regarding silage delivery rate indicates a need to educate producers on its importance for packing density. Based on the number of choppers harvesting simultaneously and their harvesting capacity, it is likely that the weight of a single packing tractor, the most common choice, did not match the delivery rate. On half of the dairies, silage structures were not sized according to feedout needs. Increasing the silage storage area, adding more packing tractors, buying a defacer to remove silage, and creating drive-over piles were

Table 2. Dairy farm satisfaction ratings of custom harvesters in the San Joaquin Valley

\begin{tabular}{lcccc}
\hline & \multicolumn{3}{c}{ Dairies $^{1}(\%)$} \\
\cline { 2 - 4 } Custom harvester performance & 1 & 2 & 3 & \multirow{2}{*}{ Responses (no.) } \\
\hline Chopping and processing & 87.0 & 10.1 & 2.9 & 138 \\
Harvesting at the right DM & 79.0 & 18.1 & 2.9 & 138 \\
Delivery rate & 75.6 & 20.7 & 3.7 & 135 \\
Packing & 69.2 & 27.1 & 3.8 & 133 \\
\hline${ }^{1} 1$ = satisfied; 2 = needs improvement; 3 = not satisfied. & &
\end{tabular}


Table 3. Future considerations for corn silage management in San Joaquin Valley dairy farms

\begin{tabular}{lrrrr}
\hline & \multicolumn{3}{c}{ Dairies $^{1}(\%)$} & \\
\cline { 2 - 3 } Future consideration for silage management & \multicolumn{1}{c}{1} & \multicolumn{1}{c}{2} & 3 & Responses (no.) \\
\hline Harvest corn as shredlage & 3.2 & 28.2 & 68.5 & 124 \\
Build bunkers & 8.2 & 7.5 & 84.3 & 134 \\
Buy a defacer to remove silage & 13.7 & 33.1 & 53.2 & 139 \\
Plant brown mid-rib (BMR) varieties & 23.7 & 34.4 & 42.0 & 131 \\
Increase silage storage area & 24.3 & 55.9 & 19.9 & 136 \\
Increase the number of packing tractors & 29.7 & 37.0 & 33.3 & 138 \\
Create drive-over piles & 34.8 & 32.6 & 32.6 & 138 \\
Purchase a farm scale & 51.1 & 27.7 & 21.2 & 137 \\
Use inoculants & 57.8 & 17.0 & 25.2 & 135 \\
Use oxygen barrier technology film to cover & 63.2 & 23.5 & 13.2 & 136 \\
Pour concrete pads for silage storage & 64.7 & 29.5 & 5.8 & 139 \\
Kernel process corn silage & 89.0 & 6.6 & 4.4 & 136 \\
\hline
\end{tabular}

${ }^{1} 1=\mathrm{I}$ am already doing this; $2=\mathrm{I}$ would like to do this in the future; $3=\mathrm{I}$ will not do this in the future.

practices being considered by dairy producers for future implementation. Survey results will assist authors in developing relevant curriculum on silage management practices and opportunities to improve practices at harvest, packing, covering, and feedout for California's San Joaquin Valley dairies.

\section{ACKNOWLEDGMENTS}

Funding for this survey was provided by the University of California Agriculture and Natural Resources Competitive Grants Program. We gratefully acknowledge the participation of dairy producers in California's San Joaquin Valley.

\section{REFERENCES}

California Department of Food and Agriculture. 2012. California cost of production 2012 Annual. Accessed Mar. 11, 2015. http://www. cdfa.ca.gov/dairy/dairycop_annual.html.

California Regional Water Quality Control Board Central Valley Region. 2013. Order R5-2013-0122. Reissued waste discharge requirements general order for existing milk cow dairies. Accessed Mar. 11, 2015. http://www.waterboards.ca.gov/centralvalley/ board_decisions/adopted_orders/general_orders/r5-2013-0122. pdf.

Custom Insight Inc. 2010. Survey random sample calculator. Accessed Dec. 20, 2015. http://www.custominsight.com/articles/ randomsample-calculator.asp.

Der Bedrosian, M. C., K. E. Nestor Jr., and L. Kung Jr. 2012. The effects of hybrid, maturity, and length of storage on the composition and nutritive value of corn silage. J. Dairy Sci. 95:5115-5126.

Heguy, J. M., B. M. Karle, P. L. Price, and D. Meyer. 2010. Calculating field nutrient removal rates to comply with General Order for Existing Milk Cow Dairies from California's Central Valley Regional Water Quality Control Board. J. Dairy Sci. 93(E-Suppl. 1):412.
Hoffman, P. C., N. M. Esser, R. D. Shaver, W. K. Coblentz, M. P. Scott, A. L. Bodnar, R. J. Schmidt, and R. C. Charley. 2011. Influence of ensiling time and inoculation on alteration of the starchprotein matrix in high-moisture corn. J. Dairy Sci. 94:2465-2474.

Kung, L., Jr., M. R. Stokes, and C. J. Lin. 2003.Silage additives. Pages 305-360 in Silage Science and Technology. L. Al-Amoodi, ed. American Society of Agronomy, Inc., Crop Science Society of America, Inc., Soil Science Society of America, Inc., Madison, WI.

Lauer, J. 2006. Moisture content in corn silage: methods and targets for determining harvest. Pages 58-64 in Proc. Silage for Dairy Farms: Growing, Harvesting, Storing, and Feeding. Harrisburg, PA. Natural Resource, Agriculture, and Engineering Service, Ithaca, NY.

Meyer, D., P. H. Robinson, P. L. Price, R. Rauch, and J. M. Heguy. 2015. Determination of silage face surface area on commercial California dairy farms. Grass Forage Sci. http://dx.doi.org/10.1111/ gfs. 12160 .

Muck, R. E., and B. J. Holmes. 2000. Factors affecting bunker silo densities. Appl. Eng. Agric. 16:613-619.

Muck, R. E., and R. L. Huhnke. 1995. Oxygen infiltration from horizontal silo unloading practices. Trans. ASAE 38:23-31.

Muck, R. E., L. E. Moser, and R. E. Pitt. 2003. Postharvest factors affecting ensiling. Pages 251-304 in Silage Science and Technology. L. Al-Amoodi, ed. American Society of Agronomy, Inc., Crop Science Society of America, Inc., Soil Science Society of America, Inc., Madison, WI.

Shinners, K. J., D. R. Mertens, and J. Harrison. 2006. Processing whole-plant corn silage: Machine, storage, and animal perspectives. Pages 140-157 in Proc. Silage for Dairy Farms: Growing, Harvesting, Storing, and Feeding. Harrisburg, PA. Natural Resource, Agriculture, and Engineering Service, Ithaca, NY.

Silva-del-Rio, N., J. M. Heguy, and A. Lago. 2010. Feed management practices on California dairies. J. Dairy Sci. 93(E-Suppl. 1):773.

USDA. 2014. California corn for silage, 1919-2013. USDA National Agricultural Statistics Service, California Field Office. Accessed Mar. 11, 2015. http://www.nass.usda.gov/Statistics_by_State/ California/Historical_Data/Corn-S.pdf.

Whitlock, L. A., T. Wistuba, M. K. Siefers, R. Pope, B. E. Brent, and K. K. Bolsen. 2000. Effect of level of surface-spoiled silage on the nutritive value of corn silage based rations. Pages 22-24 in Cattlemen's Day 2000. Kansas State University Agricultural Experiment Station and Cooperative Extension Service, Manhattan. 